\title{
Natural biostimulants reduce the incidence of BER in sweet yellow pepper plants (Capsicum annuum L.)
}

\author{
Nada Parađiković ${ }^{1}$, Tomislav Vinković ${ }^{1 *}$, Ivana Vinković Vrček ${ }^{2}$, Monika Tkalec ${ }^{1}$ \\ ${ }^{1}$ J. J. Strossmayer University of Osijek, Faculty of Agriculture in Osijek, \\ Kralja Petra Svačića 1d, 31000 Osijek, Croatia \\ ${ }^{2}$ Institute for Medical Research and Occupational Health, Ksaverska cesta 2, \\ 10001 Zagreb, Croatia \\ e-mail: tvinkovic@pfos.hr
}

\begin{abstract}
Modern greenhouse pepper production should evolve towards more sustainable systems. The growing technique which combines soilless culture and biostimulants may reduce nutrient and water use with beneficial impact on the environment. Therefore, this work aimed to investigate effects of biostimulants application on hydroponically produced pepper plants (Capsicum annuum L.) in conditions of reduced fertilization. Positive influence of biostimulant treatment on yield parameters was observed along with significant decrease in incidence of blossom-end rot (BER) in two pepper cultivars. Biostimulants application resulted in overall increase in macro- and microelement content in fruits of treated pepper cultivars. Generally, biostimulants improved the yield of pepper plants grown hydroponically by increasing the nutrient uptake and decreasing the occurrence of BER. Thus, the application of biostimulants could be considered as a good production strategy for obtaining high yields of nutritionally valuable vegetables with lower impact on the environment.
\end{abstract}

Key words: greenhouse pepper, natural biostimulants, BER, nutrients, yield

\section{Introduction}

Sweet bell pepper (Capsicum annuum L.), an important vegetable for our daily consumption, is a horticultural crop that is traditionally supplied with high levels of chemical fertilizers, contributing to an increased contamination in environmental water bodies (del Amor 2007). The development of new production technologies has resulted in current pepper hybrids giving their maximum yields. In greenhouse production, the hydroponic system substitutes the soil, thus allowing crop cultivation in different environments, where the traditional agriculture cannot be performed (Vernieri et al. 2005). During the hydroponic cultivation of vegetables, growth disorders caused by different factors are often noticed. A common physiological disorder in modern greenhouse pepper production is a blossom-end rot (BER). BER is related to many factors including substrate salinity, high $\mathrm{Mg}, \mathrm{NH}_{4}^{+}$and/or K concentration, disturbed xylem function, fast plant growth rate, unfavorable water regime, low availability of $\mathrm{Ca}$, high temperature, high and low transpiration intensity, which may result in suppressed transport of Ca in the blossom end of the fruit (Ho and White 2005).

The induction of BER, considered as the symptom of physiological disorder caused by local Ca deficiency in young fruit, is influenced by a number of environmental factors (Ho et al. 1993). These are most likely to exert their effects by affecting the transport of $\mathrm{Ca}$ to the fruit and/or the rate of cell expansion. Although each adverse environmental condition might reduce $\mathrm{Ca}$ accumulation and/or accelerate cell expansion in a young fruit through a different physiological process, all are able to reduce the Ca concentration in distal fruit tissue to a critical level (Marcelis and Ho 1999).

The incidence of BER is infrequent, but it can cause a substantial financial loss when it occurs. It can occur in any truss throughout the seasons (Marcelis and Ho 1999), but it is only induced in fruit soon after fruit set, when the relative growth rate of young fruit is highest (Ho et al. 1987). Relative humidity around the fruit influences the mineral composition and incidence of blossom-end rot in sweet pepper fruit (Tadesse et al. 2001). Fast growth of pepper, particularly of that grown in glasshouse, correlates with lower Ca absorption from substrates and its low concentration in pepper fruits (Marcelis and Ho 1999), along with induction of BER. Since high temperature in glasshouses $\left(>28{ }^{\circ} \mathrm{C}\right)$ and low relative air humidity $(<60 \%)$, the summer conditions commonly found in glass- 
houses, favor BER onset, it is possible, by means of preventive foliar Ca application, to bring pepper fruits damage down to only 3-7\% (Benoit and Ceustermans 1999).

Nowadays, besides the yield and productivity, agriculture has to consider objectives like the food quality, the cost of production and the environmental impact of cropping systems (del Amor 2007). It is therefore imperative to grow the crop under the most optimum nutrient conditions to attain the highest profitable yield and nutritionally valuable food products. Adequate supply of macro- and microelements, as well as other nutrients in plants, realizes fruit firmness due to tissue and cell membranes integrity. Such fruits have longer shelf life, higher resistance to secondary infections, and higher tolerance to temperature stress. In many production areas, treatments with different growth promoters such as biostimulants are becoming more common for the purpose of improving production quantity and quality (Richardson et al. 2004). These products, varying in chemical composition, are proprietary and can be applied at different growth stages of plants. They often contain mixture of organic and inorganic compounds including essential macro- and micronutrients, humates, polysaccharides, amino acids, carbohydrates, glycosides and plant hormones (Adani et al. 1998, Maini 2006, Vernieri et al. 2006, Tuteja 2007, Mora et al. 2010). Most of the biostimulants are completely environment and health friendly. They increase plant mineral uptake and improve the nutrients use efficiency. Thus, several benefits for plants were identified and reported from biostimulants: increased root and shoot growth, increased resistance to stress, and increased water uptake; any of which would reduce transplant shock (Adani et al. 1998, Maini 2006, Vernieri et al. 2006, Tuteja 2007). Their effect is a result of many components that may work synergistically at different concentrations (Vernieri et al. 2005). The combination of hydroponics and biological stimulants may reduce the application of fertilizers and improves the quality of some vegetables with benefit for the environment.

Thus, the objective of this research was to evaluate four different biostimulants for their effects on yield and incidence of BER in sweet bell pepper grown under hydroponically greenhouse conditions. Additionally, we studied how application of biostimulants influenced macro- and microelement uptake by bell peppers.

\section{Materials and methods Plant production}

Investigation was carried out in two years (2009-2010) under greenhouse conditions at the agricultural trade Filakov located in Gajić, Eastern Croatia $\left(45^{\circ} 49^{\prime} \mathrm{N}, 18^{\circ} 44^{\prime} \mathrm{E}\right.$ ). Two sweet yellow pepper cultivars (Capsicum annuum L., Fam. Solanaceae), semi block pepper 'Century' F1 (Rijk Zwaan, NL) characterised by conically shaped fruits and block pepper 'Blondy' F1 (Syngenta - S\&G Vegetables) characterised by short bell shaped fruits, were planted in a rockwool and grown hydroponically. The pepper transplants were produced in rockwool blocks in commercial glasshouses of Grow Group located in Felgyo, Hungary specialized for hydroponic transplants production of various vegetable species.

The experimental design was set up in a split-plot scheme with 4 replications where each replication had 10 plants. Planting of pepper transplants was carried out on 15 February 2009 and 12 Feburary 2010 in rockwool slabs and grown till the end of the experiment. Plant density was 3 plants per square meter. Plants were trained and around a vertical string, and suckers were pruned every week. In order to improve pollination and fruit setting, plants were shaken every day when watered and bumble bees were introduced 4 weeks after transplantation. Number of fertilization rates per day in this investigation was controlled by central processor unit Priva Integro (De Lier, Netherlands) according to sun radiation, inside and outside temperature, plant growth stage, total sum of radiation, quantity and composition of drainage water and air humidity. Fertilization, which started second day after planting, was conducted by means of application of water soluble mineral or single salt based fertilizers following the standard hydroponic fertilization program and recipe. The experiment consisted of four different treatments including treated 'Blondy' F1 (BIT), control 'Blondy' F1 (BIC), treated 'Century' F1 (CenT) and control 'Century' F1 (CenC) pepper plants. In control plots, the plants received nutrient solution only, without any addition of biostimulants. To determine biostimulants effect in conditions of reduced fertilization, the concentration of nutrient solution delivered to both control and treated plots was reduced by $30 \%$ compared to prescribed recipe.

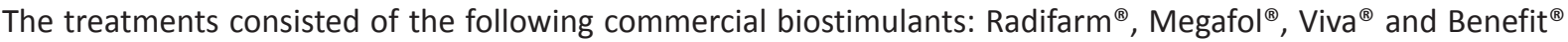
(Valagro s.p.a., Italy). All four biostimulants were applied on the each treated pepper plant. They were mixed with nutrient solution and applied by spraying or watering in given order and number of applications according to providers' recommendation where each biostimulant has specific role at certain stage of plant development. De- 
N. Parađiković et al. (2013) 22: 307-317

tailed and exact composition of biostimulants is providers' proprietary, whereas main active compounds of each biostimulant are shown in Table 1. Application of biostimulants in this kind of plant production technology belongs to new growing techniques which combine standard mineral fertilization and application of natural biostimulants. Furthermore, biostimulants cannot be considered as fertilizers since they are applied in very small quantities.

There were totally 11 harvests of fruits in 2009 and 13 harvests of fruits in 2010. The following yield parameters were determined after each harvest: total fruit yield, average fruit weight, number of non-commercial (NC) fruits (deformed and BER fruits), number of BER-affected fruits, yield loss and commercial fruit yield.

Table 1. Biostimulant composition, effects and application procedures in 2009 and 2010.

\begin{tabular}{|c|c|c|c|c|}
\hline Biostimulant & Composition & Effects & $\begin{array}{l}\text { Application } \\
\text { procedure }\end{array}$ & $\begin{array}{l}\text { Total number and periods } \\
\text { of applications (in both } \\
\text { years) }\end{array}$ \\
\hline Radifarm $^{\circledR}$ & $\begin{array}{l}\text { amino acids (asparagine, } \\
\text { arginine, tryptophane), } \\
\text { glycosides, polysaccharides and } \\
\text { organic acids }\end{array}$ & $\begin{array}{l}\text { better root growth and } \\
\text { development }\end{array}$ & $\begin{array}{l}\text { by watering } 60 \\
\mathrm{ml} \text { of } 0.25 \% \\
\text { solution per plant }\end{array}$ & $\begin{array}{l}4 \text { times: } 15 \text { Feb, } 25 \text { Feb, } 5 \\
\text { Mar and } 28 \text { Mar }\end{array}$ \\
\hline Megafol $^{\circledR}$ & $\begin{array}{l}\text { amino acids (proline and } \\
\text { tryptophane), glycosides, } \\
\text { polysaccharides, organic } \\
\text { nitrogen and organic carbon }\end{array}$ & $\begin{array}{l}\text { anti-stress effect and } \\
\text { improvement of foliar } \\
\text { growth }\end{array}$ & $\begin{array}{l}\text { by spraying } \\
55-60 \mathrm{ml} \text { of } \\
0.20 \% \text { solution } \\
\text { per plant }\end{array}$ & $\begin{array}{l}8 \text { times: every } 2 \text { weeks } \\
\text { from } 15 \text { Feb till } 25 \text { Jul } \\
\text { progressively increasing } \\
\text { the quantity of } \\
\text { biostimulant solution per } \\
\text { plant for ca. } 15 \mathrm{ml} \text { during } \\
\text { each application }\end{array}$ \\
\hline Viva $^{\circledR}$ & $\begin{array}{l}\text { organic carbon, folic acid, } \\
\text { vitamins B1, B2, B6 and PP, } \\
\text { inositol and humic acids }\end{array}$ & $\begin{array}{l}\text { improves fruit setting and } \\
\text { reduces fruit drop }\end{array}$ & $\begin{array}{l}\text { by watering } 120 \\
\mathrm{ml} \text { of } 0.25 \% \\
\text { solution per plant }\end{array}$ & $\begin{array}{l}4 \text { times: every } 10 \text { days } \\
\text { starting from } 15 \text { Jun, last } \\
\text { application on } 15 \mathrm{Jul}\end{array}$ \\
\hline Benefit $^{\circledR}$ & $\begin{array}{l}\text { organic carbon, amino acids } \\
\text { (glycine, alanine, aspartic acid } \\
\text { and glutamic acid), nucleotides, } \\
\text { free enzymes, and vitamins }\end{array}$ & $\begin{array}{l}\text { accelerates major } \\
\text { metabolic processes, } \\
\text { improves fruit setting } \\
\text { (more uniform fruit } \\
\text { weight and size) }\end{array}$ & $\begin{array}{l}\text { by spraying } \\
120-150 \mathrm{ml} \text { of } \\
0.30 \% \text { solution } \\
\text { per plant }\end{array}$ & $\begin{array}{l}8 \text { times: every } 10 \text { days } \\
\text { during investigation } \\
\text { starting from } 25 \text { Jul and } \\
\text { ending on } 25 \text { Sep }\end{array}$ \\
\hline
\end{tabular}

\section{Macro- and microelement analysis}

In order to determine effect of biostimulants on macro- and microelements content of studied pepper cultivars (cvs.) in conditions of reduced fertilization, pepper leaves and fruits of each treatment were sampled two times each year, on 15 June 2009 and 17 June 2010 (treatments denoted with 1) and on 4 September 2009 and 7 September 2010 (treatments denoted with 2). Immediately after sampling, the pepper samples were transported to the laboratory where chemical analysis commenced. Pepper leaves were washed in distilled water. The inedible portions (placenta and seeds) of the pepper fruits were removed from the edible portion (pericarp); the edible portion was subsequently washed in distilled water and used for further analysis. Samples were dried at $70{ }^{\circ} \mathrm{C}$ and grounded. In order to determine macro- and microelements content, $1 \mathrm{~g}$ of each sample was digested with $5 \mathrm{ml}$ of a mixture of sulphuric acid, perchloric acid and hydrogen peroxide.

Total nitrogen content was determined by the Kjeldahl method (Bremmer 1965) using Distillation Unit K-350 (Büchi, Switzerland). Total phosphorus was determined by the molybdophosphoric method described by the Ging and Sturtevant (1954). The total concentration of $\mathrm{K}$ was determined by flame emission and the total concentration of $\mathrm{Ca}, \mathrm{Mg}, \mathrm{Fe}, \mathrm{Mn}, \mathrm{Zn}$ and $\mathrm{Cu}$ in the leaf and fruit samples were determined by atomic absorption spectrometry using Perkin Elmer Analyst 200 (Perkin Elmer, USA) with or without an additional dilution after wet digestion.

\section{Statistical design and analysis}

The data were subjected to correlation analysis and multiple regressions using Microsoft Excel 2007. Analysis of variance was carried out and differences between treatments and cultivars were judged by the Fisher LSD test $(p<0.05)$ using SAS 9.0 statistical package. The data are reported in tables and figures as means with standard deviations in parenthesis and error bars, respectively. 


\section{Results and discussion}

Average values of the mass and number of fruits, total and marketable yields ( $\mathrm{g} \mathrm{fruit}^{-1}$ ), yield loss, average number of non-marketable and BER fruits of treated and control plants of two pepper cultivars 'Blondy' and 'Century' studied in 2009 and 2010, are presented in the Table 2. Results regarding yielding of both pepper cultivars proved significant differences in total and marketable yield under the influence of biostimulants compared to the yield of control plants.

Table 2. Yield parameters and incidence of blossom-end-rot (BER) in 'Blondy' F1 (BI) and 'Century' F1 (Cen) pepper cultivars as affected by treatment with biostimulants in two year trials (2009 and 2010)."

\begin{tabular}{|c|c|c|c|c|c|c|c|}
\hline Year & Treatment $^{+}$ & $\begin{array}{l}\text { Total yield } \\
\text { (g plant }^{-1} \text { ) }\end{array}$ & $\begin{array}{l}\text { Number } \\
\text { of fruits } \\
\text { plant }^{-1}\end{array}$ & $\begin{array}{l}\text { Number of } \\
\text { BER fruits } \\
\text { plant }^{-1}\end{array}$ & $\begin{array}{l}\text { Fruit } \\
\text { weight } \\
\text { (g) }\end{array}$ & $\begin{array}{l}\text { Yield loss } \\
\text { (g plant }^{-1} \text { ) }\end{array}$ & $\begin{array}{l}\text { Marketable yield } \\
\quad\left(\text { g plant }^{-1}\right)\end{array}$ \\
\hline \multirow{4}{*}{$2009^{\ddagger}$} & BIT & $5982^{a}$ & $54^{c}$ & $1.5^{\mathrm{c}}$ & $110^{\mathrm{a}}$ & $300^{b}$ & $5682^{a}$ \\
\hline & $\mathrm{BIC}$ & $5242^{c}$ & $49^{d}$ & $3.2^{\mathrm{b}}$ & $106^{a}$ & $587^{a}$ & $4655^{c}$ \\
\hline & CenT & $5764^{b}$ & $68^{\mathrm{a}}$ & $1.1^{\mathrm{d}}$ & $84^{b}$ & $264^{b}$ & $5500^{b}$ \\
\hline & CenC & $5075^{d}$ & $64^{b}$ & $3.5^{\mathrm{a}}$ & $79^{c}$ & $558^{a}$ & $4517^{c}$ \\
\hline \multirow{4}{*}{2010} & BIT & $6658^{a}$ & $49^{b}$ & $0.5^{d}$ & $132^{\mathrm{a}}$ & $278^{d}$ & $6380^{\mathrm{a}}$ \\
\hline & $\mathrm{BIC}$ & $5988^{c}$ & $45^{c}$ & $2.4^{\mathrm{b}}$ & $132^{\mathrm{a}}$ & $848^{b}$ & $5140^{c}$ \\
\hline & CenT & $6571^{a, b}$ & $73^{\mathrm{a}}$ & $1.6^{c}$ & $89^{b}$ & $457^{c}$ & $6115^{b}$ \\
\hline & CenC & $6459^{b}$ & $74^{a}$ & $7.5^{\mathrm{a}}$ & $87^{b}$ & $1175^{a}$ & $5284^{c}$ \\
\hline
\end{tabular}

* Values represent means of triplicate determinations while relative standard deviation was always fewer than $12 \%$ of the values. Values marked with different letters ${ }^{a, b, c, d}$ are significantly different within one column according to the LSD test, $p=0.05$ ${ }^{+}$Control plants are denoted with $\mathrm{C}$ and treated plants with $\mathrm{T}$.

${ }^{\ddagger}$ The data for total yield, fruit weight and marketable yield, observed in 2009, have been published in the Paradikovic et al. 2011.

Our results are in accordance with previously reported studies on biostimulant use in vegetable production (Maini 2006, Vernieri et al. 2006, Russo and Berlyn 1990). The greatest total and marketable fruit yield was obtained in the year 2010 for treated 'Blondy' cultivar. The highest total yield was 6658 g plant $^{-1}$, as obtained BIT in 2010, and the lowest was $5075 \mathrm{~g} \mathrm{plant}^{-1}$ (CenC in 2009). Fruit weight was again the highest (132 g) in BIT in 2010 and lowest $(79 \mathrm{~g})$ in CenC in 2009. Significant difference $(p<0.05)$ appeared for average fruit weight between CenT and CenC treatments in favour of treated plants in 2009. As expected, 'Blondy' cv. had significantly larger fruits than 'Century' cV., but BIT had by 2.2\% increased average fruit weight compared to BIC only in 2010.

The statistical analysis of data showed that the number of BER fruits and yield loss for both pepper cultivars were significantly decreased by the biostimulants treatment in both years. Treated plants had also significantly more fruits per plant except CenT and CenC in 2010.

The optimal temperature for pepper growth is considered to be $22-28^{\circ} \mathrm{C}$. That was the case in our investigation, but the temperature was sometimes higher, up to $38^{\circ} \mathrm{C}$ in some cases, and during the night the temperature varied in the range of $15-18{ }^{\circ} \mathrm{C}$. The mean air temperatures were 28.5 and $26.5^{\circ} \mathrm{C}$ in 2009 and 2010 , respectively. Since high temperature in glasshouses $\left(>28^{\circ} \mathrm{C}\right)$ and low relative air humidity $(<60 \%)$, the summer conditions commonly found in glasshouses, favor BER onset, we recorded the highest number of BER fruits during July and August (see Figures 1 and 2). At the same time, exceptional influence of biostimulants on pepper yield parameters was observed in hot summer season when high temperatures in greenhouse caused physiological stress in plants (Figs. 1 and 2). During the rest of vegetation period, effect of biostimulants on yield parameters was less pronounced. Similar to observations by Ho et al. (1993) in tomato and by Marcelis and Ho (1999) in pepper, the incidence of BER in 'Blondy' F1 and 'Century' F1 pepper plants positively correlated with high air temperature and radiation. 


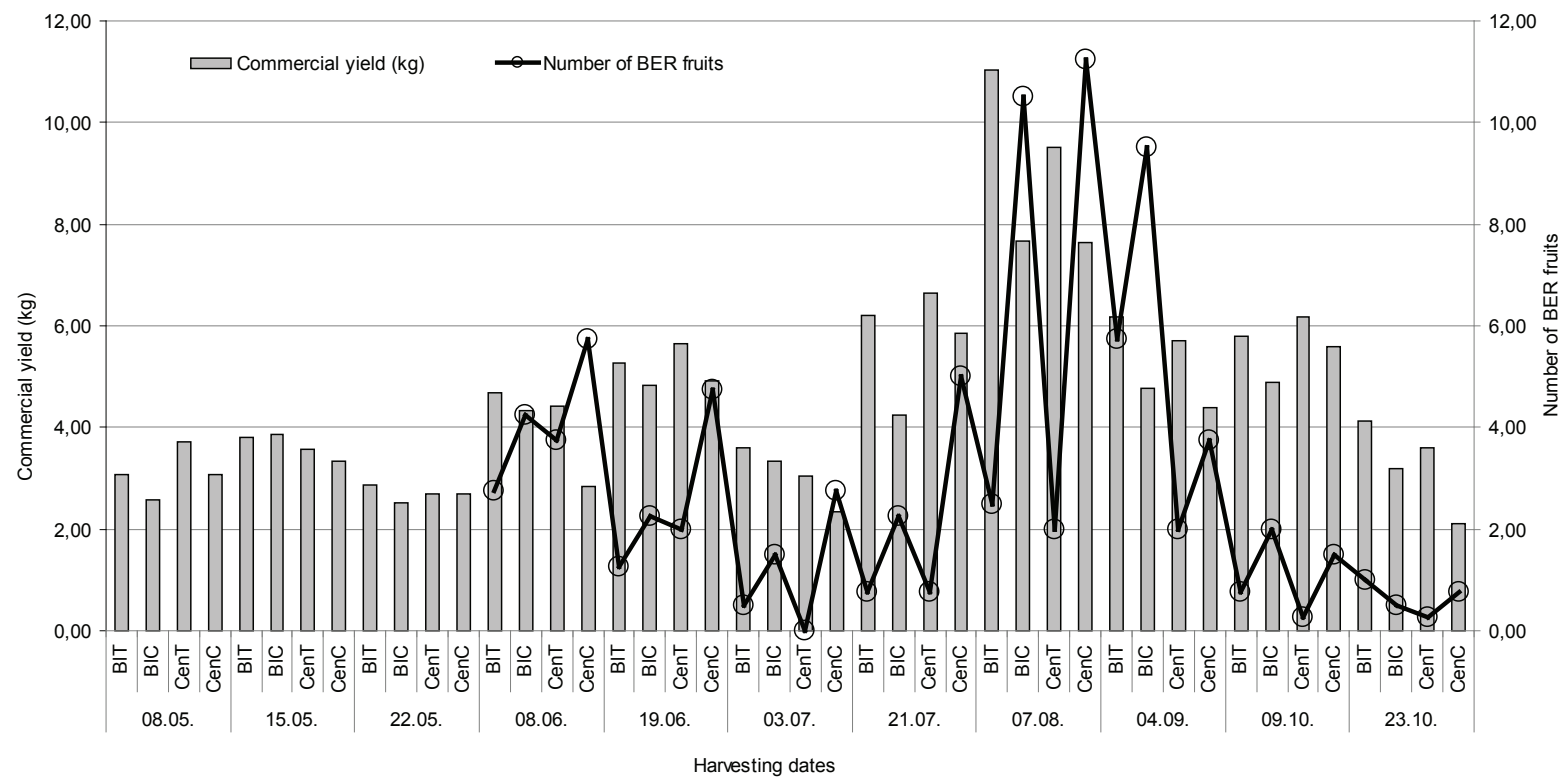

Fig. 1. Effects of biostimulants on commercial yield and incidence of blossom-end-rot (BER) fruits in treated 'Blondy' $F 1$ (BIT), treated 'Century' F1 (CenT), control 'Blondy' F1 (BIC) and control 'Century' F1 (CenC) during different harvesting dates in 2009.

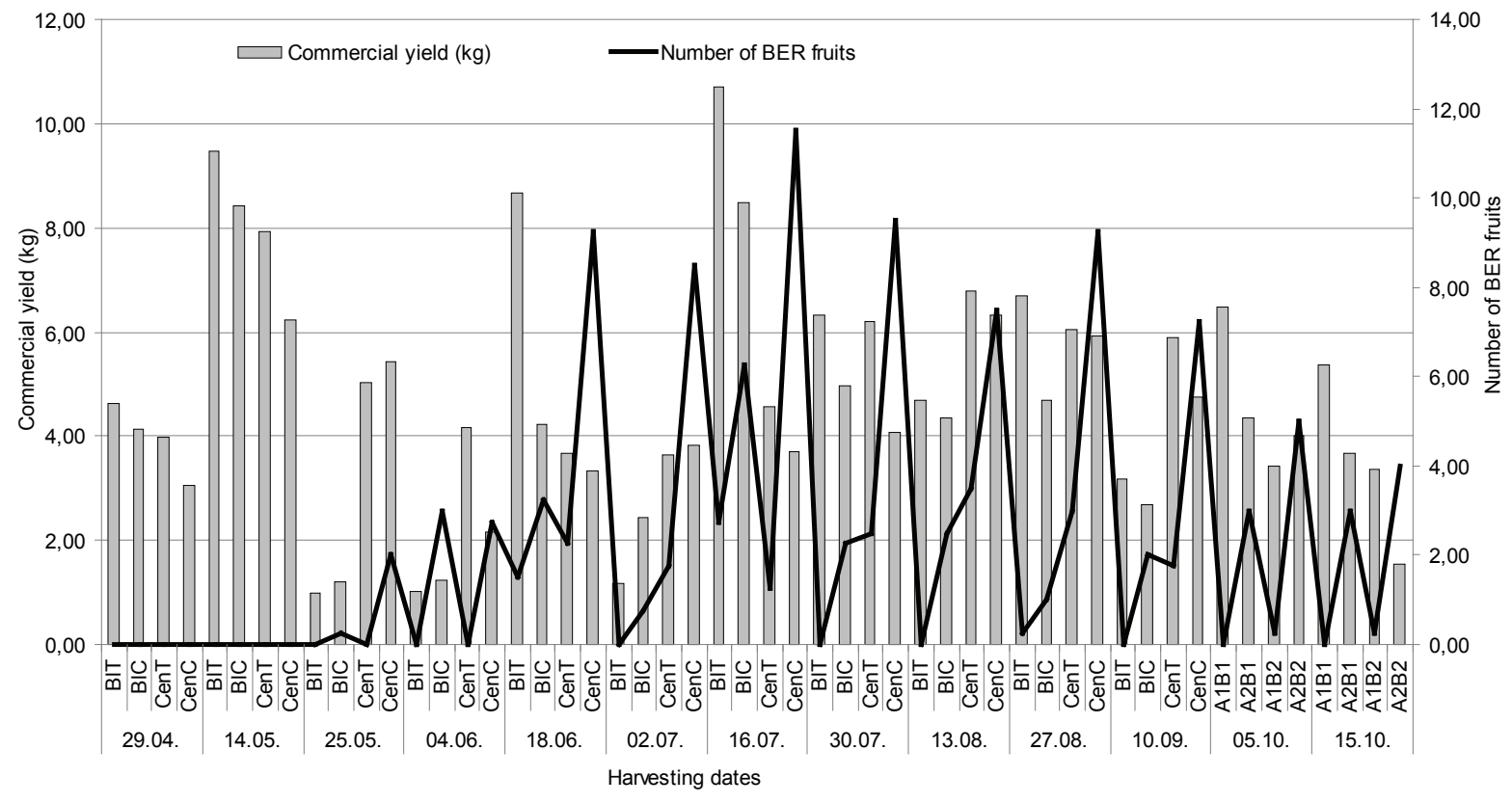

Fig. 2. Effects of biostimulants on commercial yield and incidence of blossom-end-rot (BER) fruits in treated 'Blondy' $F 1$ (BIT), treated 'Century' F1 (CenT), control 'Blondy' F1 (BIC) and control 'Century' F1 (CenC) during different harvesting dates in 2010.

Final number of BER fruits in treated 'Blondy' F1 and 'Century' F1 pepper cultivars was lower by $53 \%$ and $68 \%$, respectively, in 2009 and even by $79 \%$ and $78 \%$, respectively, lower than controls in 2010 , which highly justifies biostimulants application. Observed increase in yield of treated plants by $23 \%$ and $18 \%$ for BIT and CenT, respectively, compared to non-treated plants finally proved effectiveness of applied biostimulant in reduction of BER. In addition, calculation of the costs of biostimulant application, yield parameters and average price of peppers on the market during this research (see Table S1 in Supporting Information) demonstrated that biostimulants can be successfully used for enhancing the yield of pepper grown hydroponically.

The next hypothesis of our research was that the nutrients absorbed in the presence of biostimulants should enhance the uptake of beneficial elements in the treated pepper plants. The analyses of nitrogen $(\mathrm{N})$, phosphorus $(\mathrm{P})$, potassium $(\mathrm{K})$, calcium $(\mathrm{Ca})$, magnesium $(\mathrm{Mg})$, iron $(\mathrm{Fe})$, manganese $(\mathrm{Mn})$ and zinc $(\mathrm{Zn})$ in fruits and leaves of two pepper cultivars showed that in 2009 leaves contained more total P, K, Mg and $\mathrm{Mn}$ than in 2010 (Tables 3-4), while fruits contained more P and less Ca and Mg in 2009 compared to 2010 (Figs. 3-5). Treatment with biostimulant resulted in an increased content of almost all analysed elements in fruits of both cultivars in both years. In contrast, no such unambiguous effect of biostimulants on the leaf elemental content was found. 
N. Parađiković et al. (2013) 22: 307-317

Table 3. Effects of treatment with biostimulants on concentration of nitrogen (N), phosphorus (P), potassium (K), calcium (Ca), magnesium $(\mathrm{Mg})$, iron $(\mathrm{Fe})$, manganese $(\mathrm{Mn})$ and zinc $(\mathrm{Zn})$ in leaves of pepper cultivars during 2009. Values represent means and standard deviations are given in parenthesis.*

\begin{tabular}{|c|c|c|c|c|c|c|c|c|}
\hline Treatment $^{\dagger}$ & $\mathrm{N}(\%)$ & $\mathrm{P}(\%)$ & $\mathrm{K}(\%)$ & $\mathrm{Ca}(\%)$ & $\mathrm{Mg}(\%)$ & $\mathrm{Fe}\left(\mathrm{mg} \mathrm{kg}^{-1}\right)$ & $\mathrm{Mn}\left(\mathrm{mg} \mathrm{kg}^{-1}\right)$ & $\mathrm{Zn}\left(\mathrm{mg} \mathrm{kg}^{-1}\right)$ \\
\hline BIT I & $\begin{array}{l}2.88^{d} \\
(0.22)\end{array}$ & $\begin{array}{l}0.36^{\mathrm{d}, \mathrm{e}} \\
(0.04)\end{array}$ & $\begin{array}{c}5.17^{b} \\
(0.23)\end{array}$ & $\begin{array}{c}0.86^{a} \\
(0.06)\end{array}$ & $\begin{array}{l}0.89^{a, b} \\
(0.03)\end{array}$ & $\begin{array}{c}49.58^{b, c, d} \\
(9.24)\end{array}$ & $\begin{array}{l}94.68^{d} \\
(1.42)\end{array}$ & $\begin{array}{l}16.60^{c} \\
(3.23)\end{array}$ \\
\hline $\mathrm{BICI}$ & $\begin{array}{c}3.54^{\mathrm{a}} \\
(0.22)\end{array}$ & $\begin{array}{c}0.44^{c} \\
(0.01)\end{array}$ & $\begin{array}{c}6.00^{\mathrm{a}} \\
(0.20)\end{array}$ & $\begin{array}{c}0.92^{\mathrm{a}} \\
(0.06)\end{array}$ & $\begin{array}{c}0.97^{a} \\
(0.05)\end{array}$ & $\begin{array}{c}42.10^{c, d} \\
(9.94)\end{array}$ & $\begin{array}{c}111.03^{c, d} \\
(11.48)\end{array}$ & $\begin{array}{c}12.10^{\mathrm{c}, \mathrm{d}} \\
(1.81)\end{array}$ \\
\hline CenTI & $\begin{array}{c}3.07^{b, c, d} \\
(0.22)\end{array}$ & $\begin{array}{c}0.39^{d} \\
(0.01)\end{array}$ & $\begin{array}{l}5.57^{a, b} \\
(0.29)\end{array}$ & $\begin{array}{c}0.91^{\mathrm{a}} \\
(0.03)\end{array}$ & $\begin{array}{l}0.79^{c, d} \\
(0.04)\end{array}$ & $\begin{array}{r}60.87^{a} \\
(5.02)\end{array}$ & $\begin{array}{c}111.75^{\mathrm{c}, \mathrm{d}} \\
(2.29)\end{array}$ & $\begin{array}{l}15.10^{c} \\
(2.21)\end{array}$ \\
\hline CenC I & $\begin{array}{c}3.31^{a, b, c} \\
(0.16)\end{array}$ & $\begin{array}{c}0.63^{\mathrm{a}} \\
(0.02)\end{array}$ & $\begin{array}{c}5.95^{\mathrm{a}} \\
(0.33)\end{array}$ & $\begin{array}{c}0.57^{b} \\
(0.13)\end{array}$ & $\begin{array}{c}0.81^{b, c, d} \\
(0.11)\end{array}$ & $\begin{array}{c}43.32^{c, d} \\
(4.08)\end{array}$ & $\begin{array}{c}115.50^{c} \\
(9.14)\end{array}$ & $\begin{array}{c}9.73^{d} \\
(1.49)\end{array}$ \\
\hline BIT II & $\begin{array}{l}3.36^{a, b} \\
(0.06)\end{array}$ & $\begin{array}{c}0.34^{e} \\
(0.01)\end{array}$ & $\begin{array}{l}5.63^{a, b} \\
(0.10)\end{array}$ & $\begin{array}{c}0.89^{a} \\
(0.19)\end{array}$ & $\begin{array}{l}0.88^{b, c} \\
(0.02)\end{array}$ & $\begin{array}{l}61.95^{a} \\
(6.22)\end{array}$ & $\begin{array}{l}153.05^{a} \\
(13.82)\end{array}$ & $\begin{array}{l}32.95^{a} \\
(3.20)\end{array}$ \\
\hline BIC II & $\begin{array}{l}2.94^{c, d} \\
(0.41)\end{array}$ & $\begin{array}{l}0.39^{c, d} \\
(0.02)\end{array}$ & $\begin{array}{l}5.64^{a, b} \\
(0.30)\end{array}$ & $\begin{array}{c}0.96^{a} \\
(0.12)\end{array}$ & $\begin{array}{l}0.78^{d} \\
(0.03)\end{array}$ & $\begin{array}{c}56.85^{a, b} \\
(7.71)\end{array}$ & $\begin{array}{c}126.05^{b, c} \\
(16.03)\end{array}$ & $\begin{array}{l}22.43^{b} \\
(3.44)\end{array}$ \\
\hline CenT II & $\begin{array}{l}3.38^{a, b} \\
(0.08)\end{array}$ & $\begin{array}{l}0.39^{c, d} \\
(0.03)\end{array}$ & $\begin{array}{c}5.73^{\mathrm{a}} \\
(0.17)\end{array}$ & $\begin{array}{c}0.82^{a} \\
(0.07)\end{array}$ & $\begin{array}{l}0.88^{b, c} \\
(0.01)\end{array}$ & $\begin{array}{c}51.98^{a, b, c} \\
(2.10)\end{array}$ & $\begin{array}{l}152.55^{a} \\
(11.83)\end{array}$ & $\begin{array}{l}22.73^{b} \\
(1.20)\end{array}$ \\
\hline CenC II & $\begin{array}{c}2.88^{d} \\
(0.18)\end{array}$ & $\begin{array}{c}0.49^{b} \\
(0.06)\end{array}$ & $\begin{array}{l}5.61^{a, b} \\
(0.55)\end{array}$ & $\begin{array}{c}0.95^{\mathrm{a}} \\
(0.16)\end{array}$ & $\begin{array}{l}0.77^{d} \\
(0.03)\end{array}$ & $\begin{array}{l}40.42^{d} \\
(3.92)\end{array}$ & $\begin{array}{c}136.77^{a, b} \\
(14.36)\end{array}$ & $\begin{array}{l}14.58^{c} \\
(2.18)\end{array}$ \\
\hline
\end{tabular}

${ }^{*}$ Values marked with different letters ${ }^{\mathrm{a}, \mathrm{b}, \mathrm{c}, \mathrm{d}, \mathrm{e}}$ are significantly different within one column according to the LSD test, $p=0.05$.

‘`Blondy' F1 cultivar is denoted with BI, 'Century' F1 cultivar with Cen, control plants are denoted with C and treated plants with T, first sampling is denoted with I, and second sampling with II.

Table 4. Effects of treatment with biostimulants on concentration of nitrogen (N), phosphorus (P), potassium (K), calcium (Ca), magnesium (Mg), iron (Fe), manganese (Mn) and zinc $(\mathrm{Zn})$ in leaves of pepper cultivars during 2010. Values represent means and standard deviations are given in parenthesis.*

\begin{tabular}{|c|c|c|c|c|c|c|c|c|}
\hline Treatment $^{+}$ & $\mathrm{N}(\%)$ & $\mathrm{P}(\%)$ & K (\%) & $\mathrm{Ca}(\%)$ & Mg (\%) & $\mathrm{Fe}\left(\mathrm{mg} \mathrm{kg}^{-1}\right)$ & $\mathrm{Mn}\left(\mathrm{mg} \mathrm{kg}^{-1}\right)$ & $\mathrm{Zn}\left(\mathrm{mg} \mathrm{kg}^{-1}\right)$ \\
\hline BIT I & $\begin{array}{l}3.00^{b, c} \\
(0.22)\end{array}$ & $\begin{array}{l}0.22^{\mathrm{a}} \\
(0.01)\end{array}$ & $\begin{array}{l}3.61^{\mathrm{e}} \\
(0.03)\end{array}$ & $\begin{array}{l}0.57^{e} \\
(0.07)\end{array}$ & $\begin{array}{l}0.78^{a} \\
(0.05)\end{array}$ & $\begin{array}{c}56.66^{\mathrm{b}, \mathrm{c}} \\
(0.52)\end{array}$ & $\begin{array}{c}76.05^{a, b} \\
(8.27)\end{array}$ & $\begin{array}{l}23.33^{\mathrm{a}} \\
(1.70)\end{array}$ \\
\hline $\mathrm{BICI}$ & $\begin{array}{l}3.23^{\mathrm{a}, \mathrm{b}} \\
(0.16)\end{array}$ & $\begin{array}{l}0.22^{\mathrm{a}} \\
(0.05)\end{array}$ & $\begin{array}{l}4.23^{b, c} \\
(0.28)\end{array}$ & $\begin{array}{l}0.75^{c, d} \\
(0.12)\end{array}$ & $\begin{array}{l}0.62^{\mathrm{c}} \\
(0.06)\end{array}$ & $\begin{array}{l}65.56^{a} \\
(8.97)\end{array}$ & $\begin{array}{c}71.45^{\mathrm{a}, \mathrm{b}} \\
(4.32)\end{array}$ & $\begin{array}{c}19.87^{a, b, c} \\
(1.27)\end{array}$ \\
\hline CenT I & $\begin{array}{l}2.98^{b, c} \\
(0.26)\end{array}$ & $\begin{array}{l}0.22^{\mathrm{a}} \\
(0.01)\end{array}$ & $\begin{array}{c}3.91^{\mathrm{c}, \mathrm{d}, \mathrm{e}} \\
(0.46)\end{array}$ & $\begin{array}{l}0.64^{d, e} \\
(0.16)\end{array}$ & $\begin{array}{l}0.71^{\mathrm{a}, \mathrm{b}} \\
(0.03)\end{array}$ & $\begin{array}{l}55.03^{c} \\
(3.02)\end{array}$ & $\begin{array}{l}55.23^{c, d} \\
(4.88)\end{array}$ & $\begin{array}{c}20.47^{a, b} \\
(1.91)\end{array}$ \\
\hline CenC I & $\begin{array}{l}2.96^{b, c} \\
(0.05)\end{array}$ & $\begin{array}{l}0.20^{a, b} \\
(0.01)\end{array}$ & $\begin{array}{l}3.77^{\mathrm{d}, \mathrm{e}} \\
(0.31)\end{array}$ & $\begin{array}{c}0.67^{c, d, e} \\
(0.04)\end{array}$ & $\begin{array}{l}0.68^{b, c} \\
(0.08)\end{array}$ & $\begin{array}{c}63.33^{a, b} \\
(4.92)\end{array}$ & $\begin{array}{l}50.38^{d} \\
(12.18)\end{array}$ & $\begin{array}{c}17.29^{\mathrm{b}, \mathrm{c}} \\
(0.78)\end{array}$ \\
\hline BIT II & $\begin{array}{l}3.55^{a} \\
(0.22)\end{array}$ & $\begin{array}{l}0.18^{\mathrm{b}} \\
(0.01)\end{array}$ & $\begin{array}{l}4.40^{\mathrm{b}} \\
(0.19)\end{array}$ & $\begin{array}{l}1.06^{\mathrm{a}} \\
(0.08)\end{array}$ & $\begin{array}{l}0.77^{\mathrm{a}} \\
(0.06)\end{array}$ & $\begin{array}{c}61.41^{a, b, c} \\
(4.52)\end{array}$ & $\begin{array}{c}82.22^{\mathrm{a}} \\
(11.88)\end{array}$ & $\begin{array}{l}23.36^{\mathrm{a}} \\
(1.77)\end{array}$ \\
\hline $\mathrm{BIC} \mathrm{II}$ & $\begin{array}{l}3.06^{b, c} \\
(0.05)\end{array}$ & $\begin{array}{l}0.22^{\mathrm{a}} \\
(0.01)\end{array}$ & $\begin{array}{l}4.35^{c, b} \\
(0.25)\end{array}$ & $\begin{array}{l}0.83^{b, c} \\
(0.07)\end{array}$ & $\begin{array}{l}0.60^{c} \\
(0.02)\end{array}$ & $\begin{array}{c}58.38^{\mathrm{a}, \mathrm{b}, \mathrm{c}} \\
(3.58)\end{array}$ & $\begin{array}{l}72.40^{b} \\
(6.10)\end{array}$ & $\begin{array}{l}17.64^{\mathrm{b}, \mathrm{c}} \\
(2.54)\end{array}$ \\
\hline CenT II & $\begin{array}{l}3.27^{a, b} \\
(0.18)\end{array}$ & $\begin{array}{l}0.17^{b} \\
(0.02)\end{array}$ & $\begin{array}{l}4.36^{c, b} \\
(0.42)\end{array}$ & $\begin{array}{l}0.96^{a, b} \\
(0.10)\end{array}$ & $\begin{array}{l}0.70^{a, b} \\
(0.06)\end{array}$ & $\begin{array}{c}61.13^{\mathrm{a}, \mathrm{b}, \mathrm{c}} \\
(3.73)\end{array}$ & $\begin{array}{r}77.53^{a, b} \\
(15.66)\end{array}$ & $\begin{array}{l}21.90^{\mathrm{a}} \\
(4.91)\end{array}$ \\
\hline CenC II & $\begin{array}{c}2.74^{c} \\
(0.25)\end{array}$ & $\begin{array}{l}0.21^{\mathrm{a}} \\
(0.01)\end{array}$ & $\begin{array}{c}4.20^{b, c, d} \\
(0.06)\end{array}$ & $\begin{array}{l}0.97^{a, b} \\
(0.19)\end{array}$ & $\begin{array}{c}0.61^{c} \\
(0.01)\end{array}$ & $\begin{array}{c}57.90^{\mathrm{a}, \mathrm{b}, \mathrm{c}} \\
(5.19)\end{array}$ & $\begin{array}{c}60.40^{b, c, d} \\
(11.37)\end{array}$ & $\begin{array}{l}15.82^{c} \\
(4.01)\end{array}$ \\
\hline
\end{tabular}

*Values marked with different letters ${ }^{a, b, c, d, e}$ are significantly different within one column according to the LSD test, $p=0.05$.

‘'Blondy' F1 cultivar is denoted with BI, 'Century' F1 cultivar with Cen, control plants are denoted with C and treated plants with T, first sampling is denoted with I, and second sampling with II. 


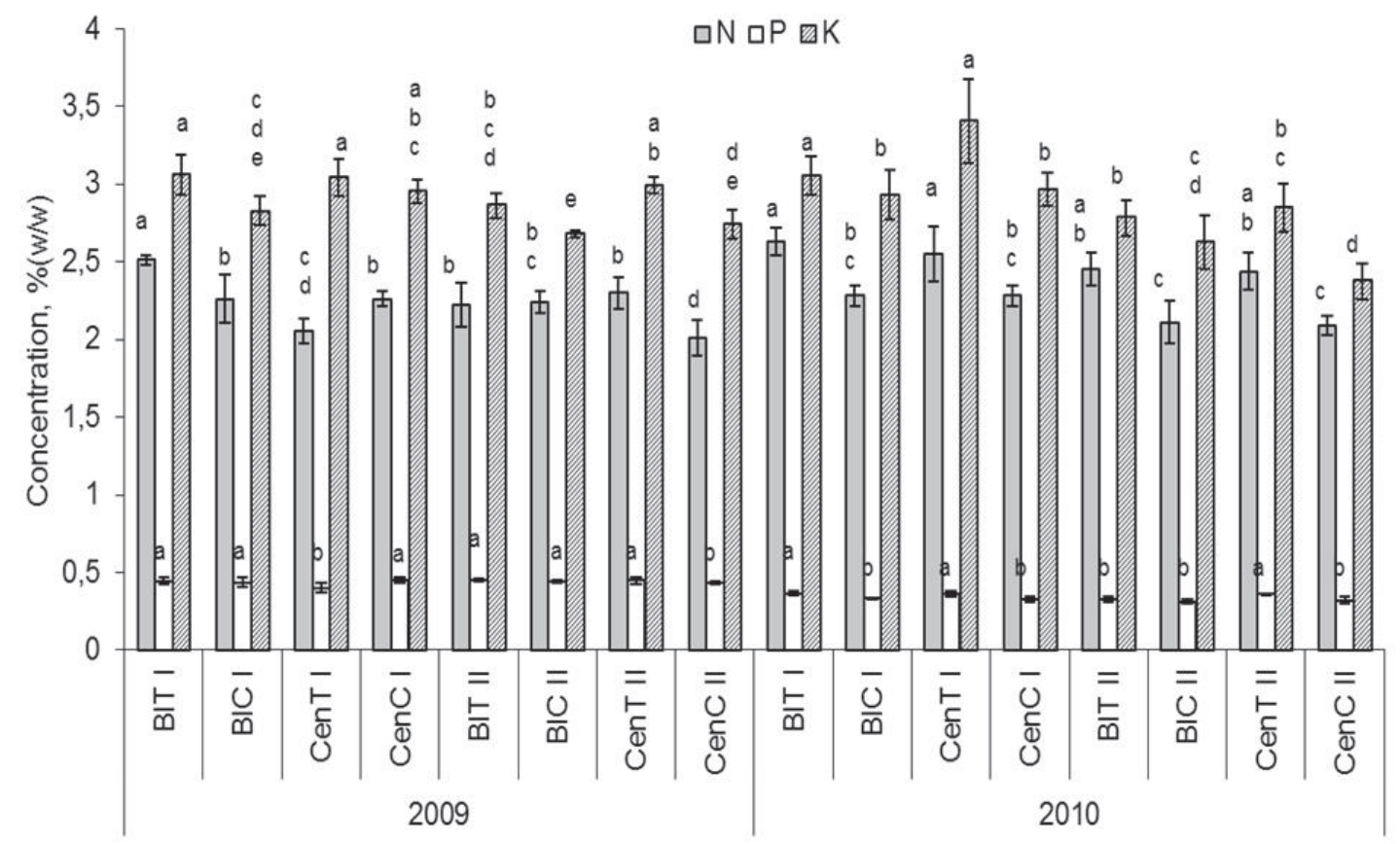

Fig. 3. Effects of biostimulants on concentration of nitrogen $(\mathrm{N})$, phosphorus $(\mathrm{P})$ and potassium $(\mathrm{K})$ in fruits of treated 'Blondy' F1 (BIT), treated 'Century' F1 (CenT), control 'Blondy' F1 (BIC) and control 'Century' F1 (CenC) after first and second sampling (denoted with I and II, respectively) in 2009 and 2010. Values, given in \% (w/w), represent means and standard deviations are presented as error bars. Values marked with different letters $a, b, c, d, e$ are significantly different within one year according to the LSD test, $p=0.05$.

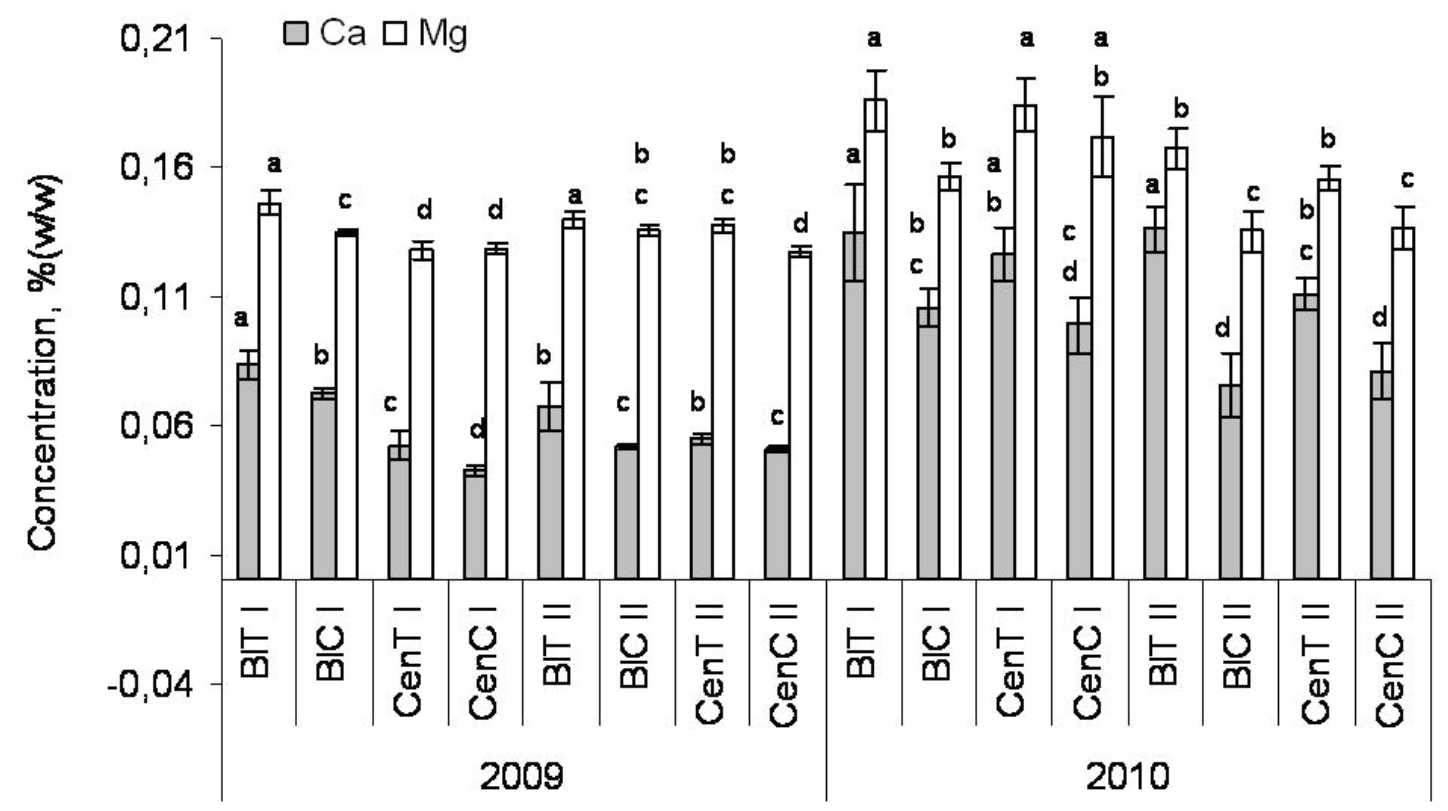

Fig. 4. Effects of biostimulants on concentration of magnesium (Mg) and calcium ( $\mathrm{Ca}$ ) in fruits of treated 'Blondy' F1 (BIT), treated 'Century' F1 (CenT), control 'Blondy' F1 (BIC) and control 'Century' F1 (CenC) after first and second sampling (denoted with I and II, respectively) in 2009 and 2010. Values, given in $\%(w / w)$, represent means and standard deviations are presented as bars. Values marked with different letters ${ }^{a, b, c, d}$ are significantly different within one year according to the LSD test, $p=0.05$. 


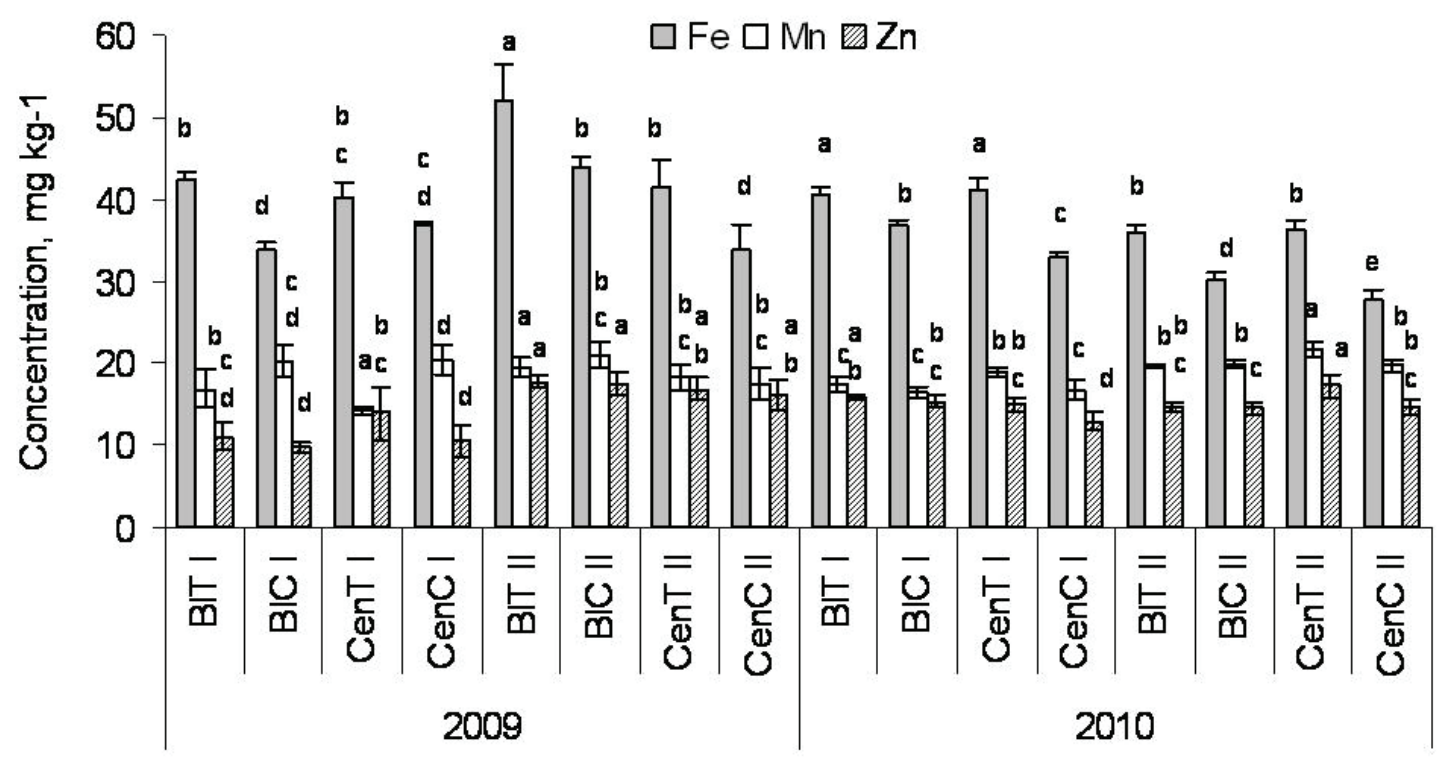

Fig. 5. Effects of biostimulants on concentration of iron (Fe), manganese (Mn) and zinc (Zn) in fruits of treated 'Blondy' F1 (BIT), treated 'Century' F1 (CenT), control 'Blondy' F1 (BIC) and control 'Century' F1 (CenC) after first and second sampling (denoted with I and II, respectively) in 2009 and 2010. Values, given in mg kg-1, represent means and standard deviations are presented as bars. Values marked with different letters ${ }^{a, b}, \mathrm{c}, \mathrm{d}, \mathrm{e}$ are significantly different within one year according to the LSD test, $p=0.05$.

Significant increase in N, K, Ca and Fe content was observed in fruits of both cultivars in both years. In Figure 4, it can be noticed that both treated cultivars recorded significantly higher values of $\mathrm{Mg}$ after second sampling as compared to controls. Observed results are to be expected if one carefully look at chemical content of applied biostimulants (Table 1). All applied biostimulants contained compounds like humic acids, amino acids, glycosides that are abundant in functional groups which lead to the active interaction with a diverse range of mineral components. Among them are carboxylic acid $(\mathrm{COOH})$ and hydroxyl $(\mathrm{OH})$ groups with ability to chelate positively charged ions.

The most interesting result is the pronounced effect of biostimulant application on increased Ca content in fruits of both cultivars in both years. This nutrient plays a key role in plant growth and development by regulating a number of fundamental cellular processes like cell division, cell elongation or cell differentiation (Reddy 2001). Thus, tissue Ca concentration in fruits of treated plants was by $25 \%$ higher than in control plants along with increased number of fruit and fruit weight by 6 and 3.6\%, respectively. At the same time, Ca leaf content of treated pepper plants was decreased, but not significantly, compared to controls in both years. It is known that plants have limited capacity for regulation of the internal distribution of Ca (Taylor et al. 2004). Thus, our results showed that biostimulants were effective in adequate distribution of $\mathrm{Ca}$ to the fruits at a period of high Ca demand. Also, in both cultivars BER incidence was negatively related to Ca concentration in the fruit tissues.

The beneficial effect of biostimulants on fruit setting and fruit yield was also apparent from the analysis of other macro- and microelements. Application of biostimulants significantly increased the Fe content in pepper fruits in both years (Fig. 5). In leaves of treated plants, Fe content was also increased compared to control, but significantly only in CenT in 2009, and in BIT and CenT in 2010 after first sampling. Enhanced solubilisation and increased extractability of iron by humic acid and amino acids may account for its increased availability. Similar findings were reported by Demir et al. (1999), and Chen and De Nobili (2004) in cucumber. The Zn content in fruits of treated peppers was also increased, but significantly only in the case of 'Century' F1 cultivar (Fig. 5). On the other hand, significant increase in $\mathrm{Zn}$ concentration in leaves was observed for both cultivars in both years but after second sampling, when two additional biostimulants, Viva ${ }^{\circledR}$ and Benefit ${ }^{\circledR}$, was applied. Content of Mn, known to show remarkable variation in its effects among plant species, was significantly increased only in fruits of CenT in 2010 and in leaves of BIT after second sampling. This result seems to be related to the antagonistic effect of $\mathrm{Ca}$ and $\mathrm{Mg}$ on Mn uptake (López-Lefebre et al. 2001). 
Considering the $\mathrm{N}$ content, our chemical analyses on leaves and fruit samples proved that total $\mathrm{N}$ content significantly increased with biostimulant application after second sampling in both years (Tables 3-4, Fig 3). The increased $\mathrm{N}$ uptake was supposed to be due to the better use efficiency of applied $\mathrm{N}$ fertilizers in the presence of humic acid and other compounds from biostimulants (David et al. 1994). Improving the efficiency of $\mathrm{N}$ remobilisation has the advantage of re-using the $\mathrm{N}$ from vegetative parts of the plant. Nitrogen is one of the most expensive nutrients to supply, and commercial fertilisers represent the major cost in plant production (Parađiković et al. 2010). This has become prohibitive for subsistence farmers. Therefore, improving $\mathrm{N}$ use efficiency leads to reduction of fertilisation cost in plant production. Subsequently, environmental damage due to nitrate leaching can be diminished. The results obtained within the present study indicate that applied biostimulants increased total $\mathrm{N}$ and $\mathrm{Ca}$ content in pepper fruits (Figs. 3 and 4) and improved the internal quality of plants by lowering leaf nitrate content. In our previous investigation, we have observed the overall increase in pigment levels of pepper plants after biostimulant application (Parađiković et al. 2011) which implies the improvement of plant external quality. The biostimulant probably affected the nitrogen metabolism, speeding up the incorporation of nitrate in the plant, through the activation of related enzymes. The increased use efficiency of nitrogen might be justified by the higher leaf pigment content in the treatments with applied biostimulants. The high chlorophyll content should increase photosynthesis process indirectly stimulating the nitrate reduction (Sherameti et al. 2002).

Thus, the combination of hydroponics and biological stimulants may reduce the application of fertilizers and improves the quality of some vegetables. Biostimulants work by increasing plant mineral uptake and improving the nutrients use efficiency. Biostimulants used in this investigation are mainly composed by amino acids, vitamins, glycosides, polysaccharides, humic acids, nucleotides and mineral nutrients. Therefore, their effect is a result of many components that may work synergistically at different concentrations.

\section{Conclusions}

Plant biostimulation has recently become an increasingly more common treatment in modern agricultural production, carried out to intensify the quantity and improve the quality of crop yield. This study showed the positive effect of biostimulant treatment both on yield and elemental content of pepper (Capsicum annuum L.) grown hydroponically in a greenhouse. The application of biostimulants directly into nutrient solution or by spraying significantly decreased the occurrence of BER fruits and increased the marketable yield. The increased accumulation of $\mathrm{N}, \mathrm{P}, \mathrm{K}, \mathrm{Ca}, \mathrm{Mg}, \mathrm{Fe}, \mathrm{Mn}$ and $\mathrm{Zn}$ in fruits and leaves of two pepper cultivars after biostimulant application was also observed. Biostimulants could not replace completely mineral nutrition in hydroponics, but could help balanced uptake of nutrients and their distribution in the plant. The findings in this investigation have provided useful information on more economical production strategy. Thus, the combination of hydroponics and biostimulants application could help in reducing the fertilizer application and consequently become environmental friendly production of vegetables in greenhouses.

\section{Acknowledgements}

This study was an integral part of project nr. VIII-5-28/08 under title "Application of new technologies in hydroponic pepper growing" sponsored by Ministry of Agriculture, Fisheries and Rural Development of Republic of Croatia.

\section{References}

Adani, F., Genevini, P., Zaccheo, P. \& Zocchi, G. 1998. The effect of commercial humic acid on tomato plant growth and mineral nutrition. Journal of Plant Nutrition 21: 561-575.

Benoit, F. \& Ceustermans, N. 1999. Sweet peppers. Blossom-end rot in sweet peppers: possibilities of calcium spraying. Proeftuinnieuws 9: 15-16.

Bremmer, J.M. 1965. Total nitrogen, In: Black, C.A. (ed.). Methods of Soil Analysis, Part 2. Madison, Wisconsin, USA: American Soc. Agric. Inc. p. 1149-1178.

Chen, Y. \& De Nobili, M. 2004. The role of humic substances and DOM in metal binding and plant growth. In: Martin-Neto, L., Milori, D.M.B.P. \& da Silva, W.T.L. (eds.). Humic Substances and Soil and Water Environment. Sao Paulo, Brazil: Proceedings of the XII International Meeting of the International Humic Substances Society. p. 195-197.

David, P.P., Nelson, P.V. \& Sanderers, D.C. 1994. A humic acid improves growth of tomato seedling in solution culture. Journal of Plant Nutrition 17: 173-184.

del Amor, F.M. 2007. Yield and fruit quality response of sweet pepper to organic and mineral fertilization. Renewable Agriculture and Food System 22: 233-238. 
Demir, K., Gnes, A., Inal, A. \& Alpaslan, M. 1999. Effects of humic acids on the yield and mineral nutrition of cucumber (Cucumis sativus L.) grown with different salinity levels. Acta Horticulturae 492: 95-103.

Ging, N.S. \& Sturtevant, J.M. 1954. The heat of hydrolysis of inorganic pyrophosphate. Journal of the American Chemical Society 76: 2087-2091.

Ho, L.C. \& White, P.J. 2005. A cellulare Hypothesis for the induction of blossom-end rot in tomato fruit. Annals in Botany 95: 571-581.

Ho, L.C., Belda, R., Brown, M., Andrews, J. \& Adams, P. 1993. Uptake and transport of calcium and the possible causes of blossomend rot in tomato. Journal of Experimental Botany 44: 509-518.

Ho, L.C., Grange, R.I. \& Picken, A.J. 1987. An analysis of the accumulation of water and dry matter in tomato fruit. Plant Cell and Environment 10: 157-162.

López-Lefebre, L.R., Rivero, R.M., García, P.C., Sánchez, E., Ruiz, J.M. \& Romero, L. 2001. Effect of calcium on mineral nutrient uptake and growth of tobacco. Journal of the Science, Food and Agriculture 81: 1334-1338.

Maini, P. 2006. The experience of the first biostimulant, based on aminoacids and peptides: a short retrospective review on the laboratory researches and the practical results. Fertilitas Agrorum 1(1): 29-43.

Marcelis, L.F.M. \& Ho, L.C. 1999. Blossom-end rot in relation to growth rate and calcium content in fruits of sweet pepper (Capsicum annuum L.). Journal of Experimental Botany 50: 357-363.

Mora, V., Bacaicoa, E., Zamarreño, E.-M., Aguirre, E., Garnica, M., Fuentes, M. \& García-Mina, J.-M. 2010. Action of humic acid on promotion of cucumber shoot growth involves nitrate-related changes associated with the root-to-shoot distribution of cytokinins, polyamines and mineral nutrients. Journal of Plant Physiology 167: 633-642.

Parađiković, N., Teklić, T., Vinković, T., Kanižai, G., Lisjak, M., Mustapić-Karlić, J. \& Bučan, L. 2010. The incidence of BER-affected tomato fruits under influence of the form of $\mathrm{N}$ fertilizer. Journal of Food, Agriculture and Environment 8: 201-205.

Parađiković, N., Vinković, T., Vinković Vrček, I., Žuntar, I., Bojić, M. \& Medić-Šarić, M. 2011. Effect of natural biostimulants on yield and nutritional quality: an example of sweet yellow pepper (Capsicum annuum L.) plants. Journal of the Science of Food and Agriculture 91:2146-2152.

Reddy, A.S.N. 2001. Calcium: silver bullet in signaling. Plant Science 160: 381-404.

Richardson, A.D., Aikens, M., Berlyn, G.P. \& Marsh, P. 2004. Drought stress and paper birch (Betula papyrifera) seedlings: effects of an organic biostimulant on plant health and stress tolerance, and detection of stress effects with instrument-based, noninvasive methods. Journal of Arboriculture 30: 52-60.

Russo, R.O. \& Berlyn, G.P. 1990. The use of organic biostimulants to help low-input sustainable agriculture. Journal of Sustainable Agriculture 1: 19-42.

Sherameti, S., Sopory, K., Trebicka, A., Pfannschmidt, T. \& Oelmuller, R. 2002. Photosynthetic electron transport determines nitrate reductase gene expression and activity in higher plants. Journal of Biological Chemistry 277: 46594-46600.

Tadesse, T., Nichols, M.A., Hewwett, E.W. \& Fisher, K.J. 2001. Relative humidity around the fruit influences the mineral composition and incidence of blossom-end rot in sweet pepper fruit. Journal of Horticultural Science and Biotechnology 76: 9-16.

Taylor, M.D., Locascio, S.J. \& Alligood, M.R. 2004. Blossom-end rot incidence of tomato affected by irrigation quantity, calcium source, and reduced potassium. Horticultural Science 39: 1110-1115.

Tuteja, N. 2007. Links mechanisms of high salinity tolerance in plants. Methods in Enzymology 428: 419-438.

Vernieri, P., Borghesi, E., Ferrante, A. \& Magnani G. 2005. Application of biostimulants in floating system for improving rocket quality. Journal of Food, Agriculture and Environment 3: 86-88.

Vernieri, P., Borghesi, E., Tognoni, F., Ferrante, A., Serra, G. \& Piaggesi, A. 2006. Use of biostimulants for reducing nutrient solution concentration in floating system. Acta Horticulturae 718: 477-484. 
Supporting Information

Table S1. Increase in net income per 1 ha calculated according to the costs of biostimulant application, yield parameters and average price of peppers on the market during this research.

\begin{tabular}{|c|c|c|c|c|c|}
\hline Type of cost & \multicolumn{2}{|r|}{ Unit } & Quantity & Price per unit $(€)$ & TOTAL (€) \\
\hline Radifarm $^{\circledast}$ & \multicolumn{2}{|r|}{$\mathrm{L}$} & 18 & 8 & 144 \\
\hline Megafol $^{\circledR}$ & \multicolumn{2}{|r|}{$\mathrm{L}$} & 29 & 18 & 522 \\
\hline Viva ${ }^{\circledR}$ & \multicolumn{2}{|r|}{ L } & 36 & 14 & 504 \\
\hline Benefit $^{\circledR}$ & \multicolumn{2}{|r|}{ L } & 97 & 10 & \multirow[t]{2}{*}{970} \\
\hline $\begin{array}{l}\text { Spraying (labour and } \\
\text { sprayer cost) }\end{array}$ & \multicolumn{2}{|r|}{$\mathrm{nr}$. } & 16 & 35 & \\
\hline Watering & \multicolumn{2}{|r|}{ nr. } & 8 & $N / A^{1}$ & - \\
\hline TOTAL $(€)$ & & & & \multicolumn{2}{|r|}{2700} \\
\hline Increase in net income ${ }^{2}$ & & & & \multicolumn{2}{|r|}{ cca. 24840} \\
\hline \multicolumn{6}{|c|}{ Calculation of gross income per 1 ha } \\
\hline Year & Variant & $\begin{array}{c}\text { Marketable } \\
\text { yield }(\mathrm{kg})\end{array}$ & $\begin{array}{l}\text { Average price } \\
(€)\end{array}$ & $\begin{array}{c}\text { Gross } \\
\text { income }(€)\end{array}$ & $\begin{array}{l}\text { Relative increase in gross } \\
\text { income }(\%)\end{array}$ \\
\hline \multirow[t]{4}{*}{2009} & BIT & 170400 & 0,9 & 153360 & \multirow{2}{*}{22} \\
\hline & $\mathrm{BIC}$ & 139800 & 0,9 & 125820 & \\
\hline & CenT & 165000 & 0,9 & 148500 & \multirow{2}{*}{22} \\
\hline & CenC & 135600 & 0,9 & 122040 & \\
\hline \multirow[t]{4}{*}{2010} & $\mathrm{BIT}$ & 191400 & 0,9 & 172260 & \multirow{2}{*}{24} \\
\hline & $\mathrm{BIC}$ & 154200 & 0,9 & 138780 & \\
\hline & CenT & 183600 & 0,9 & 165240 & \multirow{2}{*}{16} \\
\hline & CenC & 158400 & 0,9 & 142560 & \\
\hline
\end{tabular}

${ }^{1}$ Watering was performed through the irrigation system thus representing insignificant cost.

${ }^{2}$ Increase was calculated on the basis of average price of $0,9 €$ per $\mathrm{kg}$ of pepper fruits and plant density of 3 plants per $\mathrm{m}^{2}$ in both investigation years and both pepper hybrids. 